\title{
Gastric Histopathology of White Rats After Administration of Kedondong Leaves Extract
}

\author{
I Wayan Sudira, I Made Merdana* and Ketut Budiasa \\ Veterinary Pharmacology and Pharmacy Laboratory, Faculty of Veterinary Medicine, Udayana University \\ Jl. P.B. Sudirman, Denpasar, Bali, Indonesia \\ *Corresponding author: imade_merdana@unud.ac.id
}

\begin{abstract}
This study aims to determine the effect of ethanol extract of Kedondong leaves (Spondias dulcis G. Forst) on the gastropathological histology of white rats (Mus musculus). 25 healthy male white rats with weights 200-250 g were randomly divided into five groups. A control group was only given a placebo. The treatment group of kedondong leaf ethanol extract sequentially with a dose of $125,250,500$ and $1,000 \mathrm{mg} / \mathrm{kg} /$ day for 21 days orally. On the $22^{\text {nd }}$ day, all of the animals were sacrificed for the gastric collection, followed by processing of histopathological preparations with Hematoxylin Eosin (HE) staining. The results of the study are all treatment groups were found gastric histology changes in the form of mild inflammatory cell infiltration, mild fatty degeneration and mild necrosis. The number of mice that experienced histopathological changes are different in each group. It can be concluded that the oral administration of kedondong leaf ethanol extract with a range at a dose of $125-1,000 \mathrm{mg} / \mathrm{kg} / \mathrm{d}$ for 21 days does not cause significant histopathological structure disturbance in the stomach of male white rats.
\end{abstract}

Keywords: kedondong leaves extract; gastic; histopathological; white rat

\section{INTRODUCTION}

Kedondong plants (Spondias dulcis, G. Frost) are reported contained chemical compounds such as saponins, flavonoids, and tannins. These compounds are distributed in the fruit, leaves, bark and root bark. The use of traditional medicine is now increasingly popular because it is safer than synthetic chemical drugs and also more economical.

The medicines that enter the body generally will experience absorption, distribution and binding of work targets to cause effects. With or without biotransformation, the drug will then be excreted from the body (Bustami 1995, Muschler). Oral administration will involve various organs of the digestive tract, one of which is the absorption process in the gastric. The stomach is a part of the digestive tract that can dilate, the structure resembles a sac that functions to pulverize food in the digestive process which is assisted by hydrochloric acid (HCl) and enzymes such as pepsin, renin, lipase and paracrine hormone.

The use of traditional medicine as a support for modern medicine that is provided with preparations that are easier to use. In some instances, the content of active ingredients in herbal plants is suspected to be toxic, so that the right dose is needed in its use. As a preventive measure to avoid the occurrence of toxicity, further research needs to be done. In current research, a study was conducted to determine the effect of the ethanol extract of kedondong leaf on the gastric histopathological change of the white rats.

\section{RESEARCH METHOD}

\section{Preparation of kedondong leaves extract}

Fresh dried kedondong leaves are blended to powder. The powder was weighed $500 \mathrm{~g}$ and soaked with $90 \%$ ethanol as much as $1.5 \mathrm{~L}$ (ratio of 1: 3 ), and mixed with a shaker for 3 hours. The mixture is allowed to stand for 72 hours, and then filtered. the supernatant was evaporated with a rotary evaporator and ethanol extract from kedondong leaves was obtained. The extract was stored in the refrigerator at $-20^{\circ} \mathrm{C}$ before use.

\section{Research procedure and animals development}

The study was carried out in the Veterinary Pharmacology and Pharmacy Laboratory of the Faculty of Veterinary Medicine, Udayana University. The experimental animal has followed the protocol and received approval by the Ethical Commission for the Use Animals in Research and Education.

The treatment of kedondong leaf extract with various dosage levels is given for 21 days orally. P0 as a control was only given a placebo. Each treatment group was given a dose of ethanol extract of kedondong leaves as follows $\mathrm{P} 1=125 \mathrm{mg} / \mathrm{kg} / \mathrm{d}, \mathrm{P} 2=250 \mathrm{mg} / \mathrm{kg} / \mathrm{d}, \mathrm{P} 3=500$ $\mathrm{mg} / \mathrm{kg} / \mathrm{d}$ and $\mathrm{P} 4=1,000 \mathrm{mg} / \mathrm{kg} / \mathrm{d}$. On the $22^{\text {nd }}$ day all animals were sacrificed and gastric organs were taken for his topathological studies. 


\section{Histopathological examination}

Histopathological preparation of sample was carried out according to the Kiernan method (2001). The gastric organs were taken and stored in NBF $10 \%$, then the samples are processed histopathological preparations and stained by haematoxyline and eosine stain. Histopathological observation using a light microscope with magnification of 400x, each in 5 microscopic field of view. The observed changes were inflammation cell infiltration, fatty degeneration, and necrosis. Assessment of histopathological changes was done by skoring namely; score 0 - no change, score 1 - if there are mild changes (focal), score 2 - if there is a moderate change (multifocal) and score 3 - if there is a heavy change (diffuse).

\section{Statistic analisys}

Histopathological score analysis using the Kruskall Wallis followed by Mann-Whitney test if there were differences found among groups.

\section{RESULTS AND DISCCUSION}

Result

Histopathological examination results of white rats gastric showing the normal structure in control groups (Fig. 1). Gastric histopathological changes are observed included inflammatory cell infiltration and hydrophic degeneration (Fig. 2 and Fig. 3). features include inflammatory cell infiltration, hydropic and fatty degeneration and necrosis found in groups of animals given extracts at a doses 500 and $1000 \mathrm{mg} / \mathrm{kg}$ (Fig. 4 and Fig. 5). Tabulation of the results of histopathological examination is presented in Table 1.

The results of Kruskal-Wallis statistical analysis showed that giving various doses of ethanol extract of Kedondong leaves had no significant effect $(\mathrm{P}>0.05)$ on degeneration, inflammatory cell infiltration and necrosis.

TABEL 1

THE NUMBER OF EXPERIMENT AL ANIMALS UNDERGOING GAST RIC HIST OPALOGICAL CHANGES

\begin{tabular}{|c|c|c|c|c|c|c|c|c|c|c|c|c|}
\hline \multirow[t]{2}{*}{ Group } & \multicolumn{4}{|c|}{$\begin{array}{c}\text { Inflammatory Cell } \\
\text { Infiltration }\end{array}$} & \multicolumn{4}{|c|}{ Degeneration } & \multicolumn{4}{|c|}{ Necrosis } \\
\hline & 0 & 1 & 2 & 3 & 0 & 1 & 2 & 3 & 0 & 1 & 2 & 3 \\
\hline P0 (control) & - & - & - & - & - & - & - & - & - & - & - & - \\
\hline P1 (125 mg/kg) & - & 1 & - & - & - & 1 & - & - & - & - & - & - \\
\hline P2 $(250 \mathrm{mg} / \mathrm{kg})$ & - & 1 & - & - & - & 2 & - & - & - & - & - & - \\
\hline P3 (500 mg/kg) & - & 2 & - & - & - & 2 & - & - & - & 1 & - & - \\
\hline P4 $(1.000 \mathrm{mg} / \mathrm{kg})$ & - & 3 & - & - & - & 2 & - & - & - & 2 & - & - \\
\hline
\end{tabular}

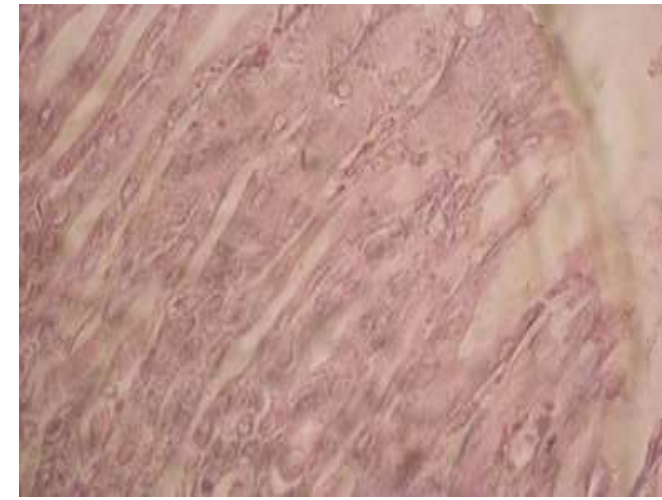

Fig. 1. The histological structure of the gastric is normal in the control group

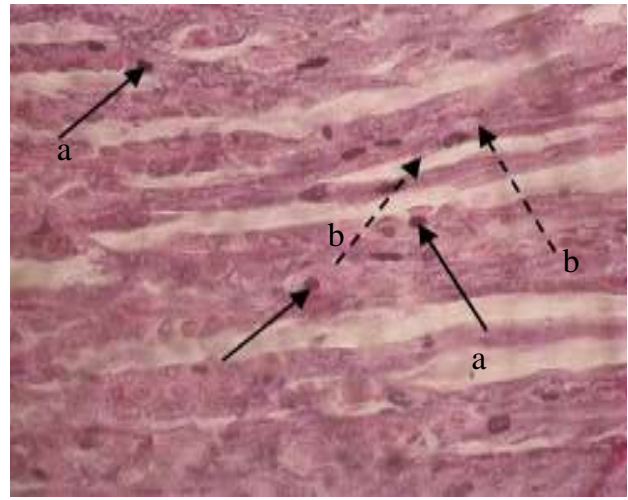

Fig. 2. Gastric histopathology of $\mathrm{P} 1$ groups $(125 \mathrm{mg} / \mathrm{kg})$, found changes: a) infiltration of inflammatory cells, and b) hydropic degeneration 


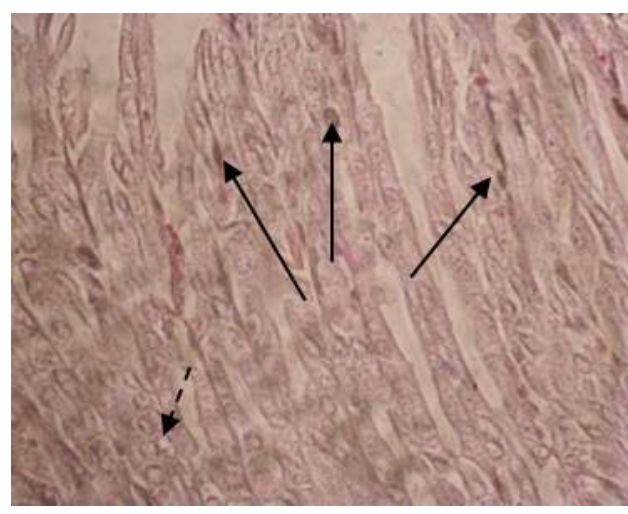

Fig. 3. Gastric histopathology of $\mathrm{P} 1$ groups $(250 \mathrm{mg} / \mathrm{kg})$, found changes: a) infiltration of inflammatory cells, and b) hydropic degeneration

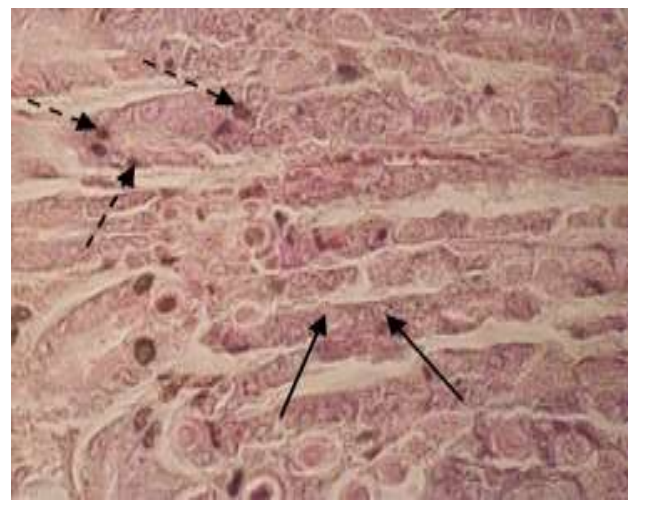

Fig. 4. Gastric histopathology of P1 groups $(500 \mathrm{mg} / \mathrm{kg})$, found changes: a) infiltration of inflammatory cells, b) hydropic degeneration, and c) necrosis

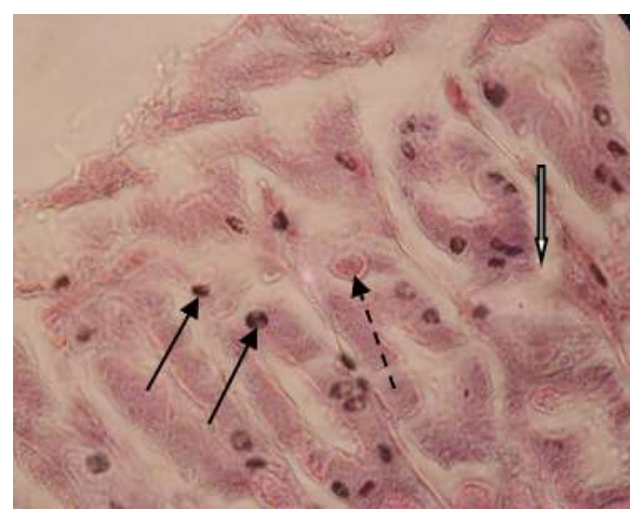

Fig. 5. Gastric histopathology of P1 groups $(1,000 \mathrm{mg} / \mathrm{kg})$, found changes: a) infiltration of inflammatory cells, b) hydropic degeneration, and c) necrosis

\section{Discussion}

Kedondong plants are used as herbal medicines because they contain chemical compounds in the form of flavonoids, saponins and tannins. These active compounds contained in other plants are reported to have antioxidant, antibacterial, antiinflamatory, anticancer and immunostimulatory activities. Flavonoids found in all parts of plants such as leaves, roots, wood, skin, fruit and seeds. The mechanism of action of flavonoids in suspected by activating enzymes in the stomach to eliminate mutagen compounds and carcinogens (Markham, 1998). In pharmacokinetics, there may be some active ingredients from herbal contents that are potentially toxic to the body when consumed, and will first be accommodated in the stomach.

Histologically the stomach consists of four layers, the mucosal layer which is the barrier layer between the body and various materials, including food, as well as toxins and microorganisms that enter through the digestive tract (Bloom and Fawcet, 2004). The first barrier component of the gastric mucosal defense is goblet cells that secrete mucus. The mucus has the ability to facilitate the gliding of food along the digestive tract and prevent epithelial chemical damage. Mucus secretion can also protect the gastric mucosa from foreign agents, such as microorganisms, worms, acidic substances and others (Guyton and Hall, 1997). With enzymatic mechanisms and selection in the digestive system, giving ethanol extract of kedondong leaves on histopathological examination found no toxic in the gastric.

Microscopic examination of gastric histopathology of white rats were found to experience fatty degeneration and hydropic degeneration at all animals group. were degenerated. Fat degeneration is usually characterized by vacuoles of varying magnitude and in severe cases pushing the nucleus to the edge. Fat in the cytoplasm of the pat cell forces the cell nucleus to the edges that appear on microscopic examination. The cells with hydrophic degeneration are usually characterized by enlarged cytoplasm which can be accompanied by the presence of empty spaces (vacuoles) with the cell nucleus remaining in the middle. An enlargement of the cell causes the cells to look tight. Hydrophic degeneration usually occurs mostly in epithelial cells. The cause, among others, due to diet or toxic substances so that lipoproteins are not formed (Himawan, 1992). Degeneration can occur physiologically depending on food and gastric metabolic activity. From various causes, the presence of toxins that enter the body of white rats in large numbers, is a major cause of degeneration in this study.

Giving ethanol extract of kedondong leaves in all animal groups was observed to experience inflammatory cell infiltration except on placebo. Inflammation of inflammatory cells was observed as follows: each of the one samples at a dose of $125 \mathrm{mg} / \mathrm{kg}$, and a dose of 250 $\mathrm{mg} / \mathrm{kg}$. Two sample at a treatment dose of $500 \mathrm{mg} / \mathrm{kg}$ had inflammatory cell infiltration. At the group at a dose of $1,000 \mathrm{mg} / \mathrm{kg}$, two out of five white rat gastric samples were found have inflammatory cell infiltration. Infiltration of inflammatory cells can occur if cell were damaged to the fundus and pylorus stimulates the release of inflammatory mediators. The series of tasks of the inflammatory mediator begins with acute inflammation and ends with healing.

His topathological observation of rat's stomach showed a mild necrosis at a dose of $500 \mathrm{mg} / \mathrm{kg}$ as much as a rat. 
Two mice experienced mild necrosis after being given at a dose of $1,000 \mathrm{mg} / \mathrm{kg}$. Necrosis is characterized by swelling of cells due to the efforts of the plasma membrane to regulate the mechanism of the entry and exit of ions and water. Necrosis involves a large group of cells in the tissue and produces pre-inflammatory molecules that will be infiltrated by inflammatory cells.

The cytoplasm of necrotic cells will look more acidophilic due to denaturation of cytoplasmic protein and lysosome damage. The core chromatin is lumpy, the nucleus shrinks and coloured blue, known as the picnosis process. According to Malik (1992), the gastric mucosa is a barrier between the body and various substances that enter the digestive tract. Therefore, the stomach has a protective system in layers and is very effective for maintaining the integrity of the gastric mucos. Any damage to the gastric mucosa can be repaired by accelerating the replacement of damaged cells. Epithelial cells of the digestive tract continually change and regenerate every 1-3 days. With an enzymatic mechanism and selection in the digestive system, the extract from the Kedondong plant does not cause significant structural damage to the epithelial cells and gastric glands of male white rats. Therefore, this study can recommend that the non-toxic kedondong leaves reach a dose of $1000 \mathrm{mg} / \mathrm{kg} / \mathrm{d}$ orally in white rats gastric.

\section{CONCLUSION}

In this study, it can be concluded that the administration of ethanol extract of kedondong leaves (spondias dulcis, g. forst) with at a dose of 125-1,000 $\mathrm{mg} / \mathrm{kg} / \mathrm{d}$ for 21 days has no significant effect on the histopathological structure of the white rat's gastric.

\section{REFERENCES}

[1] Soerjani. 2007. Lingkungan: Semberdaya Alam dan Kependudukan dalam Pembangunan. Jakarta: Indonesia University Press.

[2] Bloom and Fawcet. 2004. Buku Ajar Histologi. Edisi ke-12. Penerbit Buku Kedokteran EGC, 11994 : 536-46.

[3] Bustami, 1995. Introduction to Functional Telford Bringman Histology.Second Edition. 391-405. Harper Collins College Publisher. Pp: 313-316.

[4] Bohen S. 2007. Gastritis and Peptic Ulcers Diseases. http:www.mercklibrary/gastritis.htm. [31 Juli 2007].

[5] Damjanov I. 2000. Buku Teks \& Atlas Berwarna Histologi. Pendit UB, penerjemah. Himawan.M, editor. Jakarta: Widya Medika. Terjemahan dari: Histopatologi A Color Atlas and Textbook. Julius. 1992. Patogenesis Tukak Peptik. Cermin Dunia Kedokteran. 79:9-13

[6] Farris, E. J. dan J. Q. Griffith. (1971). The Rat in Laboratory Investigation. Hauner Publishing Co. New York.
[7] Frappier B. 1998. Digestive System. Textbook of Veterinary Histology. Fifth Edition. Dellmann HD, Eurell JA, editor. Philadelphia: Lippincott Williams \& Wilkins. Pp: 179-183.

[8] Gartner L and JL. Hiatt. 2001. Colour Textbook of Histology. Second Edition. Philadelphia: W. B Saunders Company. Pp: 383-396.

[9] Bohen S. 2007. Gastritis and Peptic Ulcers Diseases. http:www.mercklibrary/gastritis.htm. [31 Juli 2007].

[10] Damjanov I. 2000. Buku Teks \& Atlas Berwarna Histologi. Pendit UB, penerjemah. Himawan.M, editor. Jakarta: Widya Medika. Terjemahan dari: Histopatologi A Color Atlas and Textbook. Julius. 1992. Patogenesis Tukak Peptik. Cermin Dunia Kedokteran. 79:9-13.

[11] Farris, E. J. dan J. Q. Griffith. (1971). The Rat in Laboratory Investigation. Hauner Publishing Co. New York.

[12] Frappier B. 1998. Digestive System. Textbook of Veterinary Histology. Fifth Edition. Dellmann HD, Eurell JA, editor. Philadelphia: Lippincott Williams \& Wilkins. Pp: 179-183.

[13] Gartner L and JL. Hiatt. 2001. Colour Textbook of Histology. Second Edition. Philadelphia: W. B Saunders Company. Pp: 383-396.

[14] Takeuchi K, Ukawa H, Konaka A, Kitamura M, Sugawa W. 1998. Effect of Nitric Oxide-Releasing Aspirin Derivate on Gastric Functional and Ulcerogenic Responses in Rats: Comparison With Plain Aspirin. Journal of Pharmacology and Experimental Therapeutics. 286:115-121.

[15] Wilson LM dan L Lester. 1994. Lambung dan Duodenum. Patofisiologi. Konsep Klinis Proses-Proses Penyakit. (Pathophysiology Clinical Concepts of Disease Procsses). Edisi 4. Buku 1. Sylvia A. dan Lorraine M. W, editor. Dr. Peter Anugrah, alih bahasa. Jakarta: Penerbit Buku Kedokteran EGC. Hal: 371-386. 